\title{
Aktivitas Antioksidan, Antibakteri, dan Toksisitas Ekstrak Kulit Batang Pohon Kesambi (Schleichera oleosa (Lour) Oken)
}

\section{Antioxcidant, Antibacterial Activity and Toxicity of Kesambi (Schleichera Oleosa (Lour) Oken) Brak Extracts}

Penulis

Afiliasi

\section{Puspita Sari $^{1 *}$, Purwantiningsih Sugita $^{1}$, Adi Santoso ${ }^{2}$}

\author{
${ }^{1}$ Departemen Kimia, Fakultas Matematika dan IImu Pengetahuan Alam, IPB University, Bogor, \\ Jawa Barat, 16680, Indonesia. \\ ${ }^{2}$ Puslitbang Hasil Hutan, Bogor, Indonesia.
}

\section{Kata Kunci \\ $\Rightarrow$ BSLT \\ Difusi agar \\ $\rightarrow \mathrm{DPPH}$ \\ - Schleichera oleosa (Lour) oken}

\section{Keywords \\ ○ BSLT \\ - Agar diffusion \\ $\ni D P P H$ \\ - Schleichera oleosa (Lour) oken}

Diterima 17 Juli 2019

Direvisi 24 September 2019 Disetujui 11 Oktober 2019

*Penulis Koresponding Puspita Sari email: cincin.dunia@gmail.com

\section{ABSTRAK}

Penelitian ini bertujuan untuk membandingkan aktivitas antioksidan, antibakteri, dan uji toksisitas dari berbagai jenis ekstrak kulit batang pohon kesambi (Schleichera oleosa (Lour)Oken). Tahapan penelitian meliputi proses esktraksi kulit batang kesambi dari kecamatan Mancak Serang dengan teknik maserasi bertingkat menggunakan 3 pelarut : Metanol, n-heksan, dan etil asetat. Ekstrak tersebut kemudian diuji aktivitas antioksidan, antibakteri, dan toksisitasnya. Hasil pengujian antioksidan dengan metode DPPH, antibakteri dengan metode difusi agar, dan uji toksisitas dengan metode BSLT didapat hasil penelitian menunjukkan bahwa ekstrak etil asetat memiliki aktivitas antioksidan (IC50 7,723 ppm) yang lebih baik dibandingkan dengan ekstrak metanol (IC50 7,801 ppm), dan ekstrak n-heksan (IC50 8,568 ppm). Aktivitas antibakteri menunjukkan adanya kemampuan untuk menghambat pertumbuhan bakteri Streptococcus aureus dibandingkan bakteri Escherichia coli pada konsentrasi 10000 ppm, dan hasil uji toksisitas menunjukkan bahwa ekstrak etil asetat memiliki aktivitas yang lebih baik (LC50 305,17 ppm) dibandingkan ekstrak n-heksan (LC50 374,96 ppm) dan ekstrak metanol (LC50 431,26 ppm).

\section{ABSTRACT}

This study aimed to compare antioxidant, antibacterial and toxicity tests of various types of kesambi tree bark extract (Schleichera oleosa (Lour) Oken). The research stages included extraction of kesambi stem skin from Mancak Serang sub-district with multilevel maceration techniques using 3 solvents: Methanol, n-hexane, and ethyl acetate. The extract was then tested for antioxidant activity, antibacterial, and toxicity. The results of antioxidant testing using the DPPH method, antibacterial with agar diffusion method, and toxicity test with BSLT method, the results showed that ethyl acetate extract had better antioxidant activity (IC50 7,723 ppm.) compared to extract of methanol (IC50 7,801 ppm), and n-hexane extract (IC50 8,568 ppm). Antibacterial activity showed the ability to inhibit the growth of Streptococcus aureus compared to Escherichia coli at a concentration of $10000 \mathrm{ppm}$, and the results of the toxicity test showed that ethyl acetate extract had better activity (LC50 305,17 ppm) than n-hexane extract (LC50 374, 96 ppm) and methanol extract (LC50 431,26 ppm). 


\section{PENDAHULUAN}

Saat ini masyarakat mulai beralih pada pengobatan tradisional dengan bahan-bahan alami. Penggunaan obat tradisional atau lebih dikenal dengan istilah obat herbal pada akhir-akhir ini terus meningkat. Hal ini didukung dengan adanya isu back to nature dalam memanfaatkan bahan-bahan alami sebagai obat (Santoso. 2008). Salah satu tanaman yang dapat digunakan sebagai pengobatan herbal adalah kesambi. Secara tradisional, bagian dari tanaman kesambi telah digunakan untuk pengobatan seperti penyakit kulit, disentri, gigitan ular dan dilaporkan memiliki sifat antioksidan dan antijamur (Mallik et al. 2012 dan Patra et al. 2012), ada juga penelitian yang melaporkan bahwa tanaman kesambi memiliki aktivitas antimikroba dari ekstrak serta senyawa murni yang diisolasi dari fraksi yang kurang polar (Bhatia et al. 2013). Kesambi selain bisa dimanfaatkan sebagai obat, tanaman ini juga mengandung vitamin $C$ tinggi sebagai antioksidan (Suita 2012). Berdasarkan penelitian sebelumnya terhadap buah kesambi dari tiga ekstrak yakni ekstrak n-heksana, etil asetat dan air memberikan nilai aktivitas antioksidan menggunakan metode DPPH dengan persentase berturut-turut 60,91; 43,53; dan 34,94\% (Thatavong. 2015). Penggunaan kayu kesambi di daerah Timor Indonesia digunakan untuk menekan laju pertumbuhan bakteri E. coli (Susilawati et al. 2016), sedangkan menurut Daun (1979) asap pembakaran kayu kesambi mengandung senyawa fenol yang bersifat bakteriosidal. Berdasarkan penelitian Uyun (2016) hasil uji fitokimia ekstrak kulit batang kesambi menunjukkan bahwa positif mengandung golongan senyawa triterpenoid, fenolik, alkaloid, dan flavonoid serta kulit batang kesambi mempunyai aktivitas antibakteri terhadap bakteri Staphylociccus aureus pada konsentrasi 1000 ppm menghasilkan zona hambat 14,1 $\mathrm{mm}$. Penelitian Susilawati et al. 2016 juga menyatakan bahwa ekstrak kasar kulit batang kesambi berpengaruh sangat nyata $(\mathrm{p}<0.005)$, jika dibandingkan dengan kontrol, dalam menghambat bakteri E-coli secara in vitro dengan diameter zona hambat yang berkisar antara $10.33 \pm 0.58 \mathrm{~mm}$ dan $21.6 \pm 1.2 \mathrm{~mm}$. Ghosh et al. 2011 melaporkan bahwa ekstrak methanol kulit luar batang kesambi berasal dari kaki bukit Darjeeling India teridentifikasi dua senyawa triterpenoid yaitu, taraxeron dan asam trisadenik A. Walaupun demikian, penelitian tentang komponen senyawa aktif kulit ekstrak kulit batang kesambi di Indonesia masih terbatas, begitu pula penelitian ekstrak kulit batang dari tumbuhan yang sama genus dan family dengan kesambi masih amat terbatas, pengujian sebatas hanya pada ekstrak kasarnya. Faktor perbedaan tempat tumbuh suatu tanaman dapat mempengaruhi jenis dan jumlah kandungan senayawa di dalamnya, sehingga memungkinkan adanya metabolit sekunder yang belum ditemukan. Oleh karena itu, tujuan penelitian ini adalah mengisolasi dan mengkarakterisasi komponen senyawa kulit batang kesambi. Isoalasi dilakukan melalui teknik bioassay guided, assay yang dilakukan adalah pengujian antioksidan, antibakteri, dan sitotoksis BSLT. Senyawa yang dilanjutkan karakterisisasi strukturnya adalah senyawa terpilih yang memiliki sifat antioksidan dan antibakteri kuat tetapi tidak toksis.

\section{METODE}

Penelitian ini dilakukan di Laboratorium Pusat Studi Biofarmaka Tropika LPPM IPB Bogor dan di Laboratorium Sekolah Tinggi Analis Kimia (STAK) Ciategon. Proses awal pembuatan esktrak adalah penyiapan serbuk simplisia kering. Sampel kulit batang kesambi dikeringkan dalam ruangan dengan suhu ruang. Setelah kering, semua kulit batang kesambi di haluskan hingga menjadi serbuk berukuran 60 mesh.

Proses ekstraksi menggunakan metode maserasi. Pada proses awal, sampel $(3,790 \mathrm{~kg})$ direndam menggunakan pelarut metanol $96 \%$ sebanyak $16,4 \mathrm{~L}$ selama $3 \times 24$ jam dengan dilakukan pengadukan sesekali, kemudian disaring (Ajilye et al., 2015). Filtrat yang dihasilkan lalu dievaporasi sampai diperoleh ekstrak kental metanol kulit kesambi. Ekstrak kental kemudian difraksinasi dengan $\mathrm{n}$-heksan dan etil asetat secara berturut-turut sebanyak $100 \mathrm{~mL}$ dan dipisahkan dengan menggunakan corong pisah. Setelah didapat 3 fraksi yaitu fraksi metanol, $n$-heksan dan etil asetat dilakukan pengujian antioksidan, antibakteri, dan bioaktivitas.

Metode uji antioksidan yang digunakan adalah DPPH dengan asam askorbat sebagai kontrol positif dan etanol sebagai blanko (Batubara et al. 2009). Sebanyak $100 \mu \mathrm{L}$ sampel dan $100 \mu \mathrm{L}$ DPPH (5mg DPPH dalam 100 $\mathrm{mL}$ etanol) masing-masing ditambahkan pada sumur mikroplate. Setelah inkubasi selama 30 menit, diukur absorbansinya pada panjang gelombang $517 \mathrm{~nm}$ dan kemudian dihitung aktivitas penghambatnya.

Pengujian antibakteri dilakukan dengan metode difusi agar (Tillah et al. 2017) terhadap S. aureus (ATTC 6538) dan E. coli (ATTC 25922) diinkubasi pada suhu $37^{\circ} \mathrm{C}$ selama 24 jam dalam medium cair. Selanjutnya medium agar ditambahkan dengan inokulum bakteri dan ditempatkan ke dalam cawan Petri lalu dibiarkan hingga memadat. Kemudian ke dalam medium yang 
telah padat dimasukkan kertas cakram Whatman $6 \mathrm{~mm}$ sebanyak 6 buah, 4 buah kertas cakram ditetesi $20 \mu \mathrm{L}$ larutan sampel dengan berbagai konsentrasi (20.000; 10.000; 5000; 2500 ppm), sisanya ditetesi dengan kontrol positif (tetrasiklin 1000 ppm) dan kontrol negatif (DMSO 20\%). Kemudian cawan Petri diinkubasi pada suhu $37^{\circ} \mathrm{C}$ selama 24 jam, lalu diukur zona hambat yang terbentuk.

Pengujian toksisitas dilakukan dengan menggunakan metode Brine Shrimp Lethality Test (BSLT) menggunakan larva udang Artemia salina Leach.sebagai objek pengamatan. Sebanyak $20 \mathrm{mg}$ sampel dicampurkan dengan air laut sebanyak $10 \mathrm{~mL}$, lalu dihomogenkan (stok sampel 2000 ppm). Sebanyak $1000 \mu \mathrm{L}$ air laut berisi larva udang 10 ekor dimasukkan ke dalam vial uji ukuran $2000 \mu \mathrm{L}$, kemudian diberi larutan sampel dengan konsentrasi berturut-turut $1000,500,100$, dan $10 \mu \mathrm{L}$ yang sudah dibuat dari larutan stok sampel 2000 ppm, didiamkan selama 24 jam. Aktivitas bioaktivitas ekstrak ditunjukkan oleh jumlah larva yang mati dibandingkan blanko. Nilai bioaktivitas ditunjukkan dengan istilah Lethal Concentration (LC50)

\section{HASIL DAN PEMBAHASAN}

Kulit batang kesambi dipotong sampai diameter \pm 2 cm kemudian di haluskan hingga menjadi serbuk berukuran 60 mesh. Sampel tersebut terlebih dahulu dikeringkan pada suhu kamar. Kulit batang kesambi hasil pengeringan didapatkan berat sebanyak 3,790 kg. Kulit batang kesambi yang sudah kering kemudian dimaserasi menggunakan metanol 96\% selama $3 \times 24$ jam. Hasil maserasi dievaporasi diperoleh ekstrak pekat sebanyak 211,4 g, selanjutnya difraksinasi dengan nheksana dan etil asetat. Dari perlakukan ini diperoleh masing-masing fraksi n-heksana (13 mg), fraksi etil asetat $(633,7 \mathrm{mg})$ dan fraksi residu metanol $(6,0455 \mathrm{~g})$.

Dalam pengujian antioksidan digunakan asam askorbat (vitamin C) sebagai kontrol positif, pengujian antioksidan menggunakan berbagai konsentrasi berturut-turut 20 ppm, 10 ppm, 5 ppm, 2,5 ppm, 1,25 ppm, 0,625 ppm, 0,3125 ppm. Adapun hasil dari \% inhibisi masing-masing konsentrasi dari keempat ekstrak dapat dilihat pada Tabel 1. Ekstrak kulit batang kesambi memiliki nilai \% Inhibisi berkisar 3,35 \% hingga $86,61 \%$. Untuk mendapatkan nilai $I_{50}$ berdasarkan persamaan grafik hubungan antara konsentrasi terhadap \% Inhibisi dapat dilihat pada Tabel 2, kulit batang kesambi memiliki nilai $I C_{50}$ berkisar 3,061 $\pm 0,29$

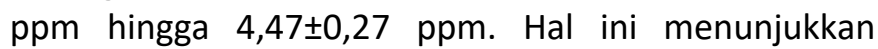
bahwa kulit batang kesambi memiliki aktivitas antioksidan kuat karena nilai $\mathrm{IC}_{50}$ dibawah 50 ppm (Tristantini et al. 2016).

Perbedaan nilai $I_{50}$ ini dapat disebabkan oleh jumlah antioksidan yang terkandung didalam ekstrak. Nilai $I_{50}$ merupakan konsentrasi efektif yang dibutuhkan untuk meredam $50 \%$ dari total DPPH. Uji aktivitas antioksidan ekstrak kulit batang kesambi menggunakan metode DPPH, karena metode ini sangat sederhana, mudah, cepat, dan peka serta hanya memerlukan sedikit sampel untuk mengevaluasi aktivitas antioksidan dari senyawa bahan alam (Molyneux, 2014).

Hasil skrining fitokimia menunjukkan bahwa fraksi etil asetat lebih banyak mengandung senyawa (triterpen, flavonoid, steroid, dan fenolik) dibandingkan dengan fraksi n-heksana (triterpen dan steroid) dan ekstrak metanol (flavonoid, fenolik dan triterpen). Pada penelitian Thind et al. 2009 dilakukan analisis fitokimia kualitataif menunjukkan adanya senyawa flavonoid dan alkaloid pada kulit kayu kesambi. Dari hasil skrining tersebut diduga aktivitas antioksidan pada fraksi etil

Tabel 1. Hasil Perhitungan \% Inhibisi Antioksidan Ekstrak Kasar dan Fraksi Kulit Batang Kesambi

\begin{tabular}{|c|c|c|c|c|}
\hline $\begin{array}{c}\text { Konsentrasi } \\
\text { (ppm) }\end{array}$ & $\begin{array}{c}\text { Ekstrak } \\
\text { Kasar Metanol } \\
\text { (\%) }\end{array}$ & $\begin{array}{c}\text { Fraksi } \\
\text { n-Heksana } \\
\text { (\%) }\end{array}$ & $\begin{array}{c}\text { Fraksi } \\
\text { Etil asetat } \\
(\%)\end{array}$ & $\begin{array}{c}\text { Fraksi } \\
\text { Residu } \\
\text { (\%) }\end{array}$ \\
\hline 20 & 86,61 & 84,76 & 84,45 & 86,51 \\
\hline 10 & 83,27 & 80,69 & 84,24 & 84,59 \\
\hline 5 & 56,49 & 47,15 & 64,25 & 63,90 \\
\hline 2,5 & 31,80 & 24,60 & 29,90 & 40,03 \\
\hline 1,25 & 15,48 & 11,98 & 10,70 & 26,32 \\
\hline 0,625 & 8,99 & 8,54 & 9,70 & 12,61 \\
\hline 0,3125 & 3,35 & 4,47 & 5,66 & 5,23 \\
\hline
\end{tabular}


Tabel 2. Hasil Nilai IC ${ }_{50}$ Antioksidan Ekstrak Kasar dan Fraksi Kulit Batang Kesambi

\begin{tabular}{lcccc}
\hline \multicolumn{1}{c}{ Sampel } & a & b & Inx & $\begin{array}{c}\text { IC } \\
\text { (ppm) }\end{array}$ \\
\hline Ekstrak Kasar & 22,25 & 21,11 & 1,32 & $3,74 \pm 0,07$ \\
Fraksi n-heksana & 21,66 & 17,61 & 1,50 & $4,47 \pm 0,27$ \\
Fraksi Etil asetat & 22,62 & 20,53 & 1,30 & $3,68 \pm 0,08$ \\
Residu Metanol & 21,92 & 25,51 & 1,12 & $3,06 \pm 0,29$ \\
Vitamin C & 24,94 & 21,97 & 1,12 & $3,10 \pm 0,02$ \\
\hline
\end{tabular}

Tabel 3. Aktivitas antibakteri Ekstrak Kulit Batang Kesambi terhadap S. aureus (ATTC 6538) dan E. coli (ATTC 25922) menggunakan metode difusi agar

\begin{tabular}{|c|c|c|c|c|c|c|}
\hline \multirow{3}{*}{ Sampel } & \multicolumn{6}{|c|}{ Zona bening $(\mathrm{mm})$ pada konsentrasi ekstrak (ppm) } \\
\hline & \multicolumn{6}{|c|}{ S. Aureus } \\
\hline & 20.000 & 10.000 & 5000 & 2500 & K+ & K- \\
\hline $\begin{array}{l}\text { Ekstrak } \\
\text { Kasar Metanol }\end{array}$ & 7,73 & - & - & - & 28,30 & 6,00 \\
\hline Fraksi n- heksana & - & - & - & - & 29,62 & 6,00 \\
\hline Fraksi Etil asetat & 8,36 & - & - & - & 28,12 & 6,00 \\
\hline \multirow{2}{*}{ Fraksi Residu } & 7,48 & - & - & - & 28,44 & 6,00 \\
\hline & \multicolumn{6}{|c|}{ E. coli } \\
\hline $\begin{array}{l}\text { Ekstrak } \\
\text { Kasar Metanol }\end{array}$ & - & - & - & - & 18,33 & 6,00 \\
\hline Fraksi n- heksana & - & - & - & - & 18,28 & 6,00 \\
\hline Fraksi Etil asetat & - & - & - & - & 18,10 & 6,00 \\
\hline Fraksi Residu & - & - & - & - & 18,34 & 6,00 \\
\hline
\end{tabular}

(-) tidak terdeteksi

$(\mathrm{K}+)$ kontrol positif (tetrasiklin $1000 \mathrm{ppm}$ )

(K-) kontrol negatif (DMSO 20\%)

asetat kulit batang kesambi disebabkan oleh adanya senyawa flavonoid. Senyawa flavonoid merupakan senyawa polifenol mempunyai kemampuan untuk menyumbangkan atom hidrogen kepada senyawa radikal bebas, aktivitas antioksidan senyawa polifenol dapat dihasilkan pada reaksi netralisasi radikal bebas atau pada penghentian reaksi berantai yang terjadi (Yuhernita dan Juniarti, 2011).

Aktivitas antibakteri ekstrak kulit batang kesambi ditetapkan menggunakan metode difusi agar (Tillah et al. 2017) terhadap S. aureus (ATTC 6538) dan E. coli (ATTC 25922). Hasil uji antibakteri dapat dilihat pada Tabel 3 menunjukkan bahwa ekstrak kulit batang kesambi dapat menghambat pertumbuhan bakteri $S$. Aureus, tetapi tidak dapat menghambat pertumbuhan E. coli. Hal ini diperkirakan karena agen antibakteri dalam ekstrak kulit batang kesambi tidak mampu melakukan penetrasi pada lapisan lipopolisakarida yang dimiliki dinding sel bakteri Gram negatif (E. coli), sedangkan pada dinding sel bakteri $S$. aureus mempunyai asam teikhoat yang sederhana yang memungkinkan untuk agen antibakteri dalam ekstrak melakukan penetrasi. E. coli juga mempunyai peptidoglikan tetapi tipis dan letaknya diantara dua membrane.

Hasil zona bening yang di dapat dengan menggunakan bakteri $S$. aureus fraksi $n$-heksan tidak memiliki aktivitas antibakteri dikarenakan tidak menghasilkan zona bening, sedangkan untuk ekstrak metanol, fraksi etil asetat dan residu didapat zona bening masing masing $7,73 \mathrm{~mm}$ (indeks daya hambat $1,73 \mathrm{~mm}$ ), $8,36 \mathrm{~mm}$ (indeks daya hambat 2,36 mm) dan $7,43 \mathrm{~mm}$ (indeks daya hambat $1,43 \mathrm{~mm}$ ). 
Tabel 4. Hasil Uji Toksisitas Ekstrak Kasar dan Fraksi Kulit Batang Kesambi dengan metode BSLT

\begin{tabular}{lcccccc}
\hline \multicolumn{1}{c}{ Sampel } & $\begin{array}{c}\text { Konsentrasi } \\
(\mathbf{p p m})\end{array}$ & $\begin{array}{c}\text { Log } \\
\text { Konsentrasi }\end{array}$ & AM & AH & $\begin{array}{c}\text { Mortalitas } \\
(\%)\end{array}$ & $\begin{array}{c}\text { LC50 } \\
\text { (ppm) }\end{array}$ \\
\hline Ekstrak Kasar & 10 & 1 & 5 & 70 & 6,67 & \\
Metanol & 100 & 2 & 22 & 45 & 32,84 & 950,63 \\
& 500 & 1,4 & 30 & 32 & 48,39 & \\
\hline \multirow{2}{*}{ Fraksi Residu } & 1000 & 3 & 50 & 10 & 83,33 & \\
Metanol & 10 & 1 & 4 & 49 & 7,55 & \\
& 100 & 2 & 28 & 23 & 54,90 & 1047,08 \\
\hline & 500 & 1,4 & 43 & 17 & 71,67 & \\
Fraksi & 1000 & 3 & 71 & 2 & 97,26 & \\
Etil Asetat & 10 & 1 & 3 & 59 & 4,84 & \\
& 100 & 2 & 16 & 32 & 33,33 & 739,39 \\
\hline \multirow{2}{*}{ Fraksi } & 500 & 1,4 & 31 & 15 & 67,39 & \\
n-heksana & 1000 & 3 & 61 & 0 & 100 & \\
& 10 & 1 & 7 & 68 & 9,33 & \\
\hline
\end{tabular}

Uji aktivitas antibakteri menunjukkan fraksi etil asetat memiliki zona penghambat tinggi terhadap $S$. aureus pada konsentrasi $20.000 \mathrm{ppm}$ sebesar $8,36 \mathrm{~mm}$. Pada penelitian Situmeang et al., 2019 didapat zona hambat pada ekstrak etil asetat yaitu $8,9 \mathrm{ppm}$ pada konsentrasi 5000 ppm, sedangkan pada penelitian Prasetya et al. (2017) biji kelengkeng memiliki aktivitas antibakteri S. aureus pada konsentrasi 100.000 ppm sebesar $14,59 \mathrm{~mm}$ pada ekstrak etil asetat. Pengukuran kekuatan antibakteri telah dikemukakan oleh Davis dan Stout (1971) bila diameter daerah hambatan $5 \mathrm{~mm}$ atau kurang maka aktifitas penghambatannya dikategorikan lemah, 5-10 mm dikategorikan sedang, 10-19 $\mathrm{mm}$ dikategorikan kuat, dan $20 \mathrm{~mm}$ atau lebih dikategorikan sangat kuat. Dengan demikian dapat dikatakan bahwa fraksi etil asetat dari kulit batang kesambi memiliki kekuatan menghambat pertumbuhan bakteri sedang pada konsentrasi 20000 ppm. Hasil skrining fitokimi menunjukkan bahwa fraksi etil asetat lebih banyak senyawa (triterpen, flavonoid, steroid, dan fenolik) dibandingkan dengan fraksi n-heksana (triterpen dan steroid) dan ekstrak metanol (flavonoid, fenolik dan triterpen). Dari hasil skrining tersebut diduga aktivitas antibakteri pada fraksi etil asetat kulit batang kesambi disebabkan oleh adanya senyawa flavonoid dan fenolik. Flavonoid dapat menghambat pertumbuhan bakteri $S$. aureus dengan cara menggangu permeabilitas dinding sel bakteri, dengan terganggunya dinding sel akan menyebabkan lisis pada sel (Dewi, 2010). sedangkan menurut Pelczar dan Chan (1988) senyawa fenolik mampu membunuh mikroorganisme dengan cara mendenaturasi protein sel. Pada penelitian sebelumnya menunjukkan, bahwa ekstrak etanol $70 \%$ kulit batang kesambi memiliki aktivitas antibakteri terhadap $S$. aureus secara in vitro dengan konsentasi 6,25\% (Fernandez, 2014), senyawa triterpenoid dari kulit batang kesambi yaitu taraxerone dan triacadenic $A$ memiliki aktivitas antibakteri terhadap S. aureus (Ghosh et al., 2011).

Toksisitas dilakukan dengan menggunakan metode Brine Shrimp Lethality Test (BSLT) menggunakan larva udang Artemia salina Leach sebagai obyek pengamatan. Larva udang (Baugaard 2013). Tabel 4 menunjukkan hasil yang diperoleh pada pengujian bioaktivitas dengan metode BSLT. Berdasarkan data hasil uji bioaktivitas pada tabel tersebut dapat diketahui bahwa kulit batang kesambi baik dari ekstrak kasar, fraksi n-heksana, fraksi etil asetat, dan fraksi residu memberikan nilai LC50 $<1000$ ppm yang berarti masuk dalam kategori aktif atau toksis. Menurut Deskawati (2015) bila nilai LC50 < 1000 ppm untuk ekstrak kasar masuk dalam kategori aktif atau toksis, dan jika LC50 > 1000 ppm masuk dalam kategori non toksis.

Uji toksisitas pada ekstrak tanaman biasanya dilakukan untuk megetahui tingkat keamanan suatu ekstrak dan salah satu prasyarat suatu tanaman dapat dikembangkan sebagai obat dan produk lainnya. Penelitian Trimedona et al. 2015 menunjukkan bahwa

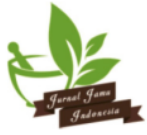


kulit batang matoa bersifat toksis dengan pelarut $\mathrm{n}$ heksana didapat LC50 sebesar $33,1 \mu \mathrm{g} / \mathrm{mL}$ dan mengidentifikasi hasil isolasi senyawa taraxerone dari ekstrak $\mathrm{n}$-heksana kulit batang matoa, sedangkan Alfin (2018) pada daun matoa menghasilkan LC50 sebesar $183 \mathrm{ppm}$ pada ekstrak etil asetat.

\section{SIMPULAN}

Pada penelitian ini, ekstrak kasar metanol, fraksi nheksana, fraksi etil asetat, dan fraksi residu metanol menunjukkan aktivitas antioksidan, antibakteri dan toksisitas. Fraksi residu Metanol memiliki aktivitas antioksidan dan toksistas lebih besar dibandingkan dengan yang lain, untuk uji antibakteri fraksi etil asetat memiliki sifat antibakteri yang lebih besar dibandingkan dengan yang lain dalam menghambat pertumbuhan bakteri $S$. aureus. Untuk fraksi etil asetat diambil untuk dilakukan uji selanjutnya yang sedang berlangsung yaitu tahap pemisahan, pemurnian dan elusidasi struktur senyawa.

\section{UCAPAN TERIMAKASIH}

Penelitian ini didukung dari pendanaan penelitian dosen Kampus Sekolah Tinggi Analis Kimia Cilegon.

\section{DAFTAR PUSTAKA}

Ajilye OO, Obuotor EM, Akinkunmi EO, Aderogba MA. 2015. Isolation and characterization of antioxidant and antimicrobial compounds from Anacardium occidentale L. (Anacardiaceae) leaf extract. King Saud University, 2015, 27: 244 -252.

Alfin S. 2018. Toksisitas ekstrak daun Matoa (Pometia pinnata) terhadap larva (Artemia salina $L$ ) dengan metode Brine Shrimp Lethality Test. Jurnal Analis Kesehatan Klinikal Sains, 6 (1).

Batubara I, Mitsunaga T, Ohasi H. 2009. Screening antiacne potency of Indonesian Medicinal Plants, antibacterial, lipase inhibition, and antioxidant activities. J Wood Sci. 55: 230-235.

Bhatia H, Kaur J, Nabdi S, Gurnani V, Chowdhury A, Reddy $\mathrm{PH}$, et al. 2013. A review on Schleichera oleosa: pharmacological and environmental aspects. J Pharm Res 2013; 6: 224-9.

Daun $\mathrm{H}, 1979$. Interaction of Wood Smoke Component and Foods. Food Technology. $33: 66-71$.

Davis WW, Stout TR. 1971. Disc plate methods of microbiological antibiotic assay. Microbiology. 22:659-665.

Deskawati E. 2015. Isolasi Senyawa Racun dari Ikan Buntal. [Tesis]. Institut Pertanian Bogor. Bogor.
Dewi FK. 2010. Aktivitas Antibakteri Ekstrak Etanol Buah Mengkudu (Morinda Citrifolia, Linnaeus) Terhadap Bakteri Pembusuk Daging Segar [Skripsi]. Fakultas Matematika Dan IImu Pengetahuan Alam. Universitas Sebelas Maret. Surakarta

Fernandez R. 2014. Uji Aktivitas Antibakteri Fraksi nheksana, Fraksi Kloroform Dan Fraaksi Air Dari Ekstrak Etanolik Kulit Batang Kesambi (Schleichera oleosa Merr.) Terhadap Bakteri Staphylococcus aureus ATCC 25923 Secara in vitro [Skripsi]. Surakarta: Fakultas Farmasi, Universitas Setia Budi.

Ghosh P, Chakraborty P, Saha A. 2011. Triterpenoids from Schleichera oleosa of Darjeeling Foothills and Their Antimicrobial Activity. Indian Journal of Pharmaceutical Sciences. 73(2): 231-233.

Mallik BK, Panda T, Padhy RN. Traditional herbal practices by the ethnic people of Kalahandi district of Odisha, India. Asian Pac J Trop Biomed 2012; 2: S988-94.

Molyneux P. 2014. The use of the stable free radical (DPPH) antioxidant activity. J Sci and Tech. 26:211219.

Patra GC, Sahu PS, Panda P, Sahoo S, Mohapatra S, Bindhani BK. Anti-mycotic effect of 'kusum oil' extract on candida albicans clinical isolates from endophthalmitis cases. Int J Pharm Bio Sci 2012; 3: B475-84.

Pelczar, M. J. dan Chan, E. C. S. 1988. Dasar-Dasar Mikrobiologi, diterjemahkan oleh Hadioetomo, R. S. Jakarta (ID) : Penerbit Universitas Indonesia, Jakarta. Prasetya, Shantina O, Soegianto L, Wijaya S. 2017. Uji Aktivitas antibakteri dan Antibiofilm Fraksi Biji Kelengkeng (Euphoria longan lour Steud) Terhadap Staphylococcus aureus ATCC 6538. [Thesis]. Widya Mandala Catholic University Surabaya. Surabaya.

Santoso HB. 2008. Ragam dan Khasiat Tanaman Obat. Jakarta Selatan. Agromedia Pustaka. Hal.50

Suita E. 2012. Seri Teknologi Pembenihan Tanaman Hutan Kesambi (Schleicera oleosa MERR.). Bogor: Balai Penelitian Teknologi Perbenihan Tanaman Hutan.

Susilawati NM, Ramona Y, Parwata IOA. 2016. Pengaruh Konsentrasi Ekstrak Kasar Kulit Batang Kusambi (Schleichera oleosa (Lour) Oken) Terhadap Pertumbuhan In Vitro Bakteri E.coli. Jurnal Metamorfosis III (2):96-102

Thatavong X. 2015. Chemical Constituents and Biological Activities From Crude Hexane Extract of Schleichera Oleosa Fruits. Chonburi: Burapha University. 
Thind S Tarunpreet, Rampal G, Agrawal K Satyam, Saxena K Ajit, Arora Saroj. 2009. Diminution of free radical induced DNA damage by extracts/fractions from bark of Schleichera oleosa (Lour) Oken. Formerly Natural Product Letters.

Tillah M, Batubara I, Sari RK. 2017. Antimicrobial and antioxidant activities of resins and essential oil from pine (Pinus merkusii, Pinuso ocarpa, Pinus insularis) and agathis (Agathis loranthifolia). Biosaintifika. 9(1): 134-139.

Tristantini D, Ismawati A, Pradana T B, Jonathan G B. 2016. Pengujian Aktivitas Antioksidan Menggunakan
DPPH pada Daun Tanjung (Mimusops elengi L). FTI UPN. Yogyakarta.

Uyun J. 2016. Analisis Kandungan Senyawa Metabolit Sekunder Dari Kulit Batang Kesambi (Schleichera oleosa) Dan Uji Aktivitas Fraksi Terhadap Bakteri Patogen.[Skripsi]. Sekolah Tinggi Analis Kimia (STAK) Cilegon. Cilegon.

Yuhernita, Juniarti. 2011. Analisis senyawa metabolit sekunder dari ekstrak methanol daun Surian yang berpotensi sebagai antioksidan. Jakarta 10510. 